\title{
Notoginsenoside Rb1 inhibits activation of ERK and p38 MAPK pathways induced by hypoxia and hypercapnia
}

\author{
XIAOXIAO QIU, MENGXIAO ZHENG, DONG SONG, LINJING HUANG, \\ LANLAN TANG, LEI YING and WANTIE WANG
}

Department of Pathophysiology, Wenzhou Medical University, Wenzhou, Zhejiang 325035, P.R. China

Received January 21, 2015; Accepted February 23, 2016

DOI: 10.3892/etm.2016.3217

\begin{abstract}
The aim of the present study was to investigate the effect of notoginsenoside Rb1 (Rb1) on the ERK and p38 MAPK pathways in primary cultured pulmonary arterial smooth muscle cells (PASMCs) exposed to hypoxia and hypercapnia, in order to elucidate the mechanism underlying the effect of Rb1 on hypoxia and hypercapnia-induced pulmonary vasoconstriction (HHPV). PASMCs were isolated from Sprague-Dawley rats. The cells were divided into five groups: Normal (N), hypoxia and hypercapnia $(\mathrm{H}), \mathrm{Rb}_{\mathrm{L}}, \mathrm{Rb}_{\mathrm{M}}$ and $\mathrm{Rb}_{\mathrm{H}}$ groups. $\mathrm{N}$ group cells were cultured under $5 \% \mathrm{CO}_{2}$ and $21 \% \mathrm{O}_{2} . \mathrm{H}, \mathrm{Rb}_{\mathrm{L}}, \mathrm{Rb}_{\mathrm{M}}$ and $\mathrm{Rb}_{\mathrm{H}}$ groups were cultured under $6 \% \mathrm{CO}_{2}$ and $1 \% \mathrm{O}_{2}$. Prior to the hypoxia and hypercapnia exposure, $\mathrm{Rb}_{\mathrm{L}}, \mathrm{Rb}_{\mathrm{M}}$ and $\mathrm{Rb}_{\mathrm{H}}$ groups were treated with 8, 40 and $100 \mathrm{mg} / \mathrm{ml} \mathrm{Rb1}$ for $30 \mathrm{~min}$, respectively. Phosphorylated extracellular signal-regulated kinase (P-ERK) and P-p38 protein, and ERK1/2 and p38 mRNA expression levels were detected using western blot and semi-quantitative reverse transcription-polymerase chain reaction (RT-PCR) analyses, respectively. The correlations between P-ERK protein and ERK1/2 mRNA, and between P-p38 protein and p38 mRNA were evaluated. Results of western blot and RT-PCR showed hypoxia and hypercapnia increased P-ERK and P-p38 protein, and ERK1/2 mRNA,
\end{abstract}

Correspondence to: Dr Wantie Wang, Department of Pathophysiology, Wenzhou Medical University, Wenzhou Chashan Higher Education Park, Wenzhou, Zhejiang 325035, P.R. China E-mail: wantiewang0929@163.com

Abbreviations: AS, atherosclerosis; COPD, chronic obstructive pulmonary disease; ERK1/2, extracellular signal-regulated kinase; HHPV, hypoxia and hypercapnia-induced pulmonary vasoconstriction; HPV, hypoxia-induced pulmonary vasoconstriction; MAPK, mitogen activated protein kinase; PASMCs, pulmonary arterial smooth muscle cells; PH, pulmonary hypertension; PNS, Panax notoginseng saponins; p38 MAPK, p38 mitogen-activated protein kinase

Key words: notoginsenoside Rb1, p38 mitogen-activated protein kinase, extracellular signal-regulated kinase, pulmonary arterial smooth muscle cells, hypoxia and hypercapnia respectively $(\mathrm{P}<0.05)$. Rb1 suppressed the increased P-ERK and P-p38 protein, and ERK1/2 and p38 mRNA by hypoxia and hypercapnia $(\mathrm{P}<0.05)$. $\mathrm{P}-\mathrm{ERK}$ protein was positively correlated with ERK1 $(r=0.5, \mathrm{P}<0.01)$ and ERK2 mRNA $(\mathrm{r}=0.977, \mathrm{P}<0.01) . \mathrm{P}-\mathrm{p} 38$ protein was positively correlated with $\mathrm{p} 38$ mRNA $(\mathrm{r}=0.884, \mathrm{P}<0.01)$. Thus, the present results indicate that Rb1 may ameliorate HHPV by suppressing ERK and p38 pathways. The study provides an experimental basis for investigating the clinical use of Rb1 in the management of HHPV-related disorders.

\section{Introduction}

Chronic obstructive pulmonary disease (COPD) is a type of obstructive lung disease characterized by progressive incompletely reversible poor airflow. COPD remains a major threat to health, as it is the cause of $>3$ million cases of mortality worldwide $(1,2)$. Although COPD is incurable, its symptoms may be alleviated and its progression could be slowed down. The current available measures for reducing COPD-related mortality primarily include smoking cessation and supplemental oxygen (3). The limiting outcomes of these measures highlight the need to for novel, potent and cost-effective therapeutics for COPD (3). Although it has been demonstrated that hypoxia-induced pulmonary vasoconstriction (HPV) is a major initial factor of COPD, COPD is often accompanied by hypoxia and hypercapnia. Furthermore, hypoxia and hypercapnia-induced pulmonary vasoconstriction (HHPV) and pulmonary hypertension $(\mathrm{PH})$ are common complications of COPD (4-6). Therefore, studies investigating the alleviation of HHPV are of considerable significance in the management of COPD.

Panax notoginseng saponins (PNS), are extracted from $P$. notoginseng, a traditional Chinese medicinal herb. The main active component of the plant is panax notoginsenoside Rb1 (Rb1). Previous studies have suggested various protective effects of PNS on various cardiovascular diseases (7). For example, PNS could ameliorate atherogenesis in rabbit models by decreasing blood lipids and inhibiting inflammation (8). Furthermore, there is evidence that the protective effect of PNS on atherosclerotic (AS) rats may be mediated by increasing liver $\mathrm{X}$ receptor alpha expression, which is related to inflammation and lipid metabolism (9). Furthermore, in vivo study has indicated that total saponins of $P$. notoginseng may 
inhibit vessel restenosis following vascular intimal injury by blocking the proliferation of vascular smooth muscle cells and regulating extracellular matrix protein accumulation in the endometrium (10). However, there were are few studies concerning the impact of PNS on HHPV.

Mitogen-activated protein kinases (MAPK) pathways primarily include extracellular signal-regulated kinase (ERK1/2), p38 mitogen-activated protein kinase (p38 MAPK) and JNK pathways. It has been established that MAPK pathways are involved in smooth muscle cell proliferation, migration and regulation of intracellular calcium in pulmonary arterial smooth muscle cells (PASMCs) $(11,12)$. Furthermore, a recent study observed that notoginsenoside R1 could inhibit hypoxia-hypercapnia-induced vasoconstriction by inhibiting the ERK pathway activation in rat models (13). Our own unpublished data showed that PNS could mitigate hypoxia and hypercapnia-induced $\mathrm{PH}$ via regulation of the MAPK pathway. Thus, the present study aimed to investigate whether Rb1 could protect against HHPV, and whether its possible underlying mechanism involved MAPK pathways. PASMCs grown under the conditions of hypoxia and hypercapnia were used to emulate HHPV in the study. Prior to the hypoxia and hypercapnia exposure, PASMCs were exposed to various concentrations of the ginsenoside Rb1. The expression and phosphorylation of ERK and p38 at the protein and mRNA levels were detected.

\section{Materials and methods}

Experimental animals. Ten male specific pathogen-free Sprague-Dawley rats (weight, 200-220 g) were provided by the Experimental Animal Center of Wenzhou Medical College [Certificate No, SCXK (Zhe) 2008-0156; Wenzhou, China]. Animals received food and water ad libitum, and were housed in an environment at $18-20^{\circ} \mathrm{C}$ with $65-70 \%$ relative humidity.

$\mathrm{Rb} 1$ (purity, $>98 \%$ ) was provided by the Natural Medicine Research Center of Jilin University (Changchun, China). Rb1 was dissolved in ultrapure water, prepared as $10 \mathrm{mg} / \mathrm{ml}$ stock solution and stored in the dark at $4^{\circ} \mathrm{C}$.

Primary pulmonary artery smooth muscle cell $(P A S M C)$ isolation and culture. Rats were anesthetized via an intraperitoneal injection of $5 \%$ chloral hydrate (0.7 ml/mg; Experimental Animal Center of Wenzhou Medical University), then soaked in $75 \%$ alcohol for $3 \mathrm{~min}$. Pulmonary artery tissue segments (grade 2-4) were obtained using a dissecting microscope (Leica Microsystems Holdings $\mathrm{GmbH}$, Wetzlar, Germany) in a clean platform. Endothelial cells were removed with a sterile cotton swab. The tissue segments were then cut into small pieces, and digested with $0.2 \%$ collagenase (Sigma-Aldrich Chemie BV, Zwijndrecht, The Netherlands) for $2-4 \mathrm{~h}$ at $37^{\circ} \mathrm{C}$. After centrifugation, the supernatants were discarded and the precipitates were rinsed with Dulbecco's modified Eagle's medium (Gibco; Thermo Fisher Scientific, Inc., Waltham, MA, USA) plus 20\% Gibco fetal bovine serum (FBS) in a dish (Corning Inc., Corning, NY, USA). Then, the dish with a large number of individual muscle cells was cultured in a $5 \% \mathrm{CO}_{2}$ incubator at $37^{\circ} \mathrm{C}$. After 7 days, cells were passaged.
PASMC morphology observation. Cellular morphology was observed under an inverted phase contrast microscope (CK41; Olympus Corporation, Tokyo, Japan).

Immunocytochemical detection of smooth muscle- $\alpha$-actin in PASMCs. Smooth muscle (SM)- $\alpha$-actin in the PASMCs was detected using immunocytochemistry staining, according to the instructions of an immunohistochemistry kit (SA2008; Boster Biotechnology Co., Ltd., Wuhan, China). Cells $\left(1.0 \times 10^{4}\right.$ cells $\left./ \mathrm{cm}^{2}\right)$ grown on glass coverslips were incubated with mouse polyclonal antibody against SM- $\alpha$-actin (1:200; sc-130616; Takara Bio, Inc.). Finally, cells were stained with 3,3'-diaminobenzidine solution (Takara Bio, Inc.) for visualization. Hematoxylin (Sigma-Aldrich, St. Louis, MO, USA) was added to counterstain nuclei. The stained cells were observed under a light microscope (Olympus Corporation), with brown staining indicating a positive result. Each slide was randomly observed in three view fields. The percentage of positive cells in total cells was calculated as cell purity. PASMCs with a cell purity $>95 \%$ were selected for further experiments (14).

Drug intervention and experimental groups. PASMCs in the logarithmic phase from generations 2-5 were seeded in six-well plates at a density of $5 \times 10^{5}$ cells $/ \mathrm{ml}$, and cultured in high-glucose DMEM medium plus $10 \% \mathrm{FBS}$ at $37^{\circ} \mathrm{C}$ in a $5 \% \mathrm{CO}_{2}$ incubator. When the dish was $\sim 80 \%$ confluent (monolayer), the cells were divided into five groups: Normal group $(\mathrm{N})$; hypoxia and hypercapnia group $(\mathrm{H}) ; \mathrm{Rb}_{\mathrm{L}}$ group, $\mathrm{Rb}_{\mathrm{M}}$ group; and $\mathrm{Rb}_{\mathrm{H}}$ group. $\mathrm{N}$ group was cultured under $5 \%$ $\mathrm{CO}_{2}$ and $21 \% \mathrm{O}_{2}$ for $24 \mathrm{~h} ; \mathrm{H}, \mathrm{Rb}_{\mathrm{L}}, \mathrm{Rb}_{\mathrm{M}}$ and $\mathrm{Rb}_{\mathrm{H}}$ groups were cultured under $6 \% \mathrm{CO}_{2}$ and $1 \% \mathrm{O}_{2}$ for $24 \mathrm{~h}$. Prior to hypoxia and hypercapnia exposure, the $\mathrm{Rb}_{\mathrm{L}}, \mathrm{Rb}_{\mathrm{M}}$ and $\mathrm{Rb}_{\mathrm{H}}$ groups were cultured in serum-free medium for $24 \mathrm{~h}$, and then exposed to 8,40 and $100 \mathrm{mg} / \mathrm{ml} \mathrm{Rb1}$ for $30 \mathrm{~min}$, respectively. The $\mathrm{H}$ group was treated with the same volume of ultrapure water (Rb1 vehicle) for $30 \mathrm{~min}$.

Western blot and protein analysis. Cells were harvested, washed with ice-cold PBS three times and lysed with lysis buffer (Cell Signaling Technology, Inc., Beverly, MA, USA) for $30 \mathrm{~min}$ on ice. Following centrifugation for $5 \mathrm{~min}$ at $4^{\circ} \mathrm{C}(300 \mathrm{xg})$, the supernatants were collected and protein concentrations were evaluated using a Bicinchoninic Acid assay kit (Pierce Biotechnology, Inc., Rockford, IL, USA). Western blot was performed by adding equal quantities of protein $(50 \mu \mathrm{g})$ for each sample loaded onto 10\% sodium dodecyl sulfate-polyacrylamide gel (Invitrogen; Thermo Fisher Scientific, Inc.). Subsequently, the proteins were transferred onto immobilon-P transfer membranes (EMD Millipore, Shanghai, China). The membranes were immersed in blocking solution (5\% bovine serum albumin; Wuhan Boster Biological Technology, Ltd., Wuhan, China) for $2 \mathrm{~h}$ and incubated with appropriate primary antibodies $(1: 1,000)$ overnight at $4^{\circ} \mathrm{C}$. Then, the membranes were incubated with appropriate anti-rabbit secondary antibodies (1:4,000; Cell Signaling Technology, Inc., Danvers, MA, USA) for $2 \mathrm{~h}$ at room temperature. Finally, the membranes were developed using enhanced chemiluminescence (Super ECL Plus detection reagent; P1010; Applygen Technologies, Inc., Beijing, China). Eight duplications were made for each experiment. The following antibodies used for western blot were purchased from Cell Signaling Technology, 

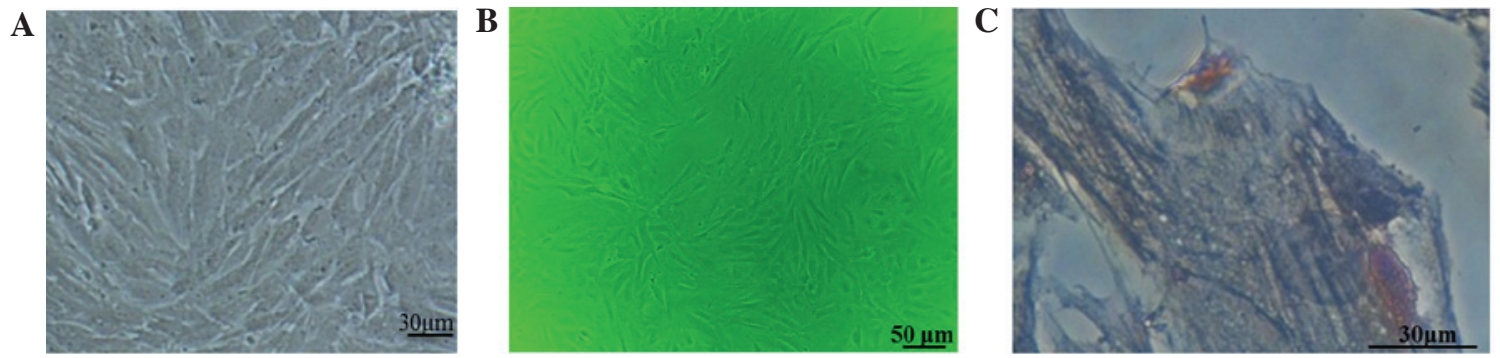

Figure 1. Pulmonary arterial smooth muscle cell (PASMC) morphological observation. (A) Primary cultured PASMCs (magnification, x200) observed under a microscope; (B) primary cultured PASMCs (magnification, $x 100$ ) observed under a microscope, (C) immunocytochemical staining of smooth muscle- $\alpha$-actin with 3,3'-diaminobenzidine and hematoxylin counterstain (magnification, x400). Brown-stained fiber filaments are parallel to the cell long axis, and the pale blue oval nucleus was located in the center of the cell.

Inc.: P-p38 rabbit monoclonal antibody (1:1,000; cat. no. 9211); P-ERK rabbit monoclonal antibody (1:1,000; cat. no. 9101), ERK rabbit monoclonal antibody (1:1,000; cat. no. 9102), horseradish peroxidase-labeled goat anti-rabbit secondary antibody $(1: 1,000$; cat. no. 7074). Quantity One gel software, version 4.4 (Bio-Rad Laboratories, Inc., Hercules, CA, USA) was used to analyze the gray value of protein bands. The ratios (P-p38 vs. T-p38, P-ERK vs. T-ERK) were defined as relative value of P-p38 and P-ERK, which were used to express phosphorylation of p38 and ERK, respectively.

Semi-quantitative reverse transcription-polymerase chain reaction ( $R T-P C R)$. Semi-quantitative RT-PCR was performed to detect mRNA level of ERK1, ERK2, and p38 using a commercial PCR kit (Takara Bio, Inc.). ERK1, ERK2 and p38 RNA were extracted from PASMCs in different groups with TRIzol reagent (Invitrogen; Thermo Fisher Scientific, Inc.) and then treated with DNase to remove genomic DNA. First strand cDNA synthesis was carried out using the cDNA Cycle kit (Invitrogen; Thermo Fisher Scientific, Inc.) and used as template DNA. The reverse transcription mixture contained $2.0 \mu 1$ template RNA, $4 \mu 15 \mathrm{X}$ reaction buffer, $1 \mu$ l Moloney murine leukemia virus reverse transcriptase $(200 \mathrm{U} / \mu \mathrm{l}), 1 \mu \mathrm{l}$ RNase inhibitor (200 U/ $\mu \mathrm{l}), 2 \mu \mathrm{l} 10 \mathrm{mmol}$ dNTPs mix and $1 \mu \mathrm{l}$ oligo $(\mathrm{dT})_{18}$ primer.

The PCR mixture included $1 \mu \mathrm{l}$ template DNA (cDNA), 12.5 $\mu$ 1 PCR Master mix (2X), $1 \mu$ l forward primer, $1 \mu$ l reverse primer and $9.5 \mu \mathrm{l}$ nuclease-free water. Primers for ERK1 were: 5'-GCTGAATCACATCCTGGGTAT-3' (upstream), and 5'-AGATCTGTATCCTGGCTGGAA-3' (downstream). Amplification for ERK 1 was performed with the following conditions: Pre-denaturation at $94^{\circ} \mathrm{C}$ for $2 \mathrm{~min}$, denaturation at $98^{\circ} \mathrm{C}$ for $10 \mathrm{sec}$, annealing at $54^{\circ} \mathrm{C}$ for $15 \mathrm{sec}$, extension at $72^{\circ} \mathrm{C}$ for $1 \mathrm{~min}$, and final extension at $72^{\circ} \mathrm{C}$ for $10 \mathrm{~min}$. The size of the amplified fragment obtained by PCR was $373 \mathrm{bp}$.

The primers for ERK2 were: 5'-GCAGGTGTTCGACGT GGGAAT-3' (upstream), and 5'-GTGCAGAACATTAGG TGAATA-3' (downstream). Amplification was performed as follows: Pre-denaturation at $94^{\circ} \mathrm{C}$ for $2 \mathrm{~min}$, denaturation at $98^{\circ} \mathrm{C}$ for $10 \mathrm{sec}$, annealing at $56^{\circ} \mathrm{C}$ for $15 \mathrm{sec}$, extension at $72^{\circ} \mathrm{C}$ for $30 \mathrm{sec}$ and final extension at $72^{\circ} \mathrm{C}$ for $10 \mathrm{~min}$. The size of the amplified fragment obtained by PCR was $394 \mathrm{bp}$.

Primers for p38 were: 5'-TCCAAGGGCTACACCAAA TC-3' (upstream), and 5'-TGTTCCAGGTAAGGGTGAGC-3' (downstream). Amplification was performed as following:
Pre-denaturation at $94^{\circ} \mathrm{C}$ for $2 \mathrm{~min}$, denaturation at $98^{\circ} \mathrm{C}$ for $10 \mathrm{sec}$, annealing at $55^{\circ} \mathrm{C}$ for $15 \mathrm{sec}$, extension at $72^{\circ} \mathrm{C}$ for $1 \mathrm{~min}$ and final extension at $72^{\circ} \mathrm{C}$ for $10 \mathrm{~min}$. The size of the amplified fragment obtained by PCR was $341 \mathrm{bp}$.

The primers for $\beta$-actin were: 5'-GAGACCTTCAACACC CCAGCC-3' (upstream), and 5'-TCGGGGGATCGGAAC CGCTCA-3' (downstream). Amplification was performed as following: Pre-denaturation at $94^{\circ} \mathrm{C}$ for $2 \mathrm{~min}$, denaturation at $98^{\circ} \mathrm{C}$ for $10 \mathrm{sec}$, annealing at $53^{\circ} \mathrm{C}$ for $15 \mathrm{sec}$, extension at $72^{\circ} \mathrm{C}$ for $30 \mathrm{sec}$ and final extension at $72^{\circ} \mathrm{C}$ for $10 \mathrm{~min}$. The size of the amplified fragment obtained by PCR was $400 \mathrm{bp}$.

Amplification was conducted using a Px2 Thermal cycler (Thermo Fisher Scientific, Inc.). PCR products were separated by electrophoresis on $1.2 \%$ agarose gel and visualized by staining with ethidium bromide (Sigma-Aldrich, St. Louis, MO, USA). The absorbance value (A) of mRNA bands was measured by MUVB-20 gel using a photographic analysis system (Ultra-Lum, Inc., Claremont, CA, USA). Densitometric analysis for semi-quantification of the PCR products was conducted using Quantity One software (Bio-Rad Laboratories, Inc.). $\beta$-actin band was used as internal reference. The ratios (ERK1 vs. $\beta$-actin, ERK 2 vs. $\beta$-actin and p38 vs. $\beta$-actin) were defined the relative A value of ERK1, ERK2 and p38, respectively. Each experiment was repeated eight times.

Statistical analysis. SPSS software, version 17.0 (SPSS, Inc., Chicago, IL, USA) was used for statistical analysis, and data were expressed as the mean \pm standard deviation. The significance of the differences between the groups was determined using one-way analysis of variance. Least significant difference and Dunnet's t-test were used for homogeneity of variance and heterogeneity of variance, respectively. The correlation between two variables was analyzed using Pearson's bivariate correlation analysis. $\mathrm{P}<0.05$ was considered to indicate a statistically significant difference.

\section{Results}

PASMC morphology and immunocytochemical observation. Fusiform PASMCs were observed under a microscope and the cell morphology remained unchanged for several generations (Fig. 1A and B). The immunocytochemistry results showed that cytoplastic positive staining of SM- $\alpha$-actin was present in $98 \%$ of PASMCs. When observed under a high-powered microscope (magnification, $\mathrm{x} 400$ ), brown-stained fiber 
A

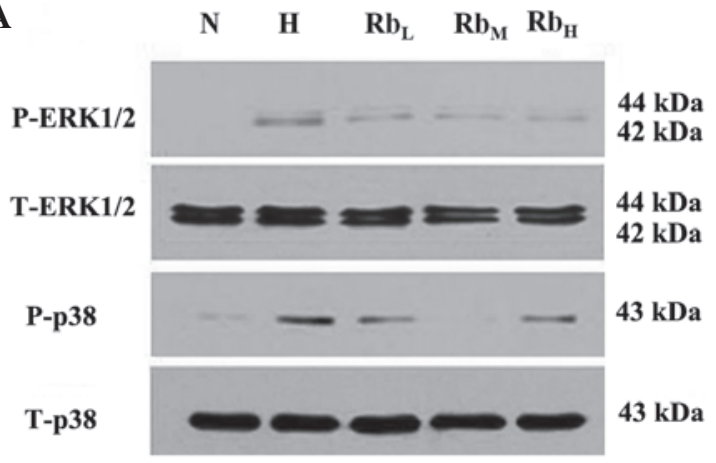

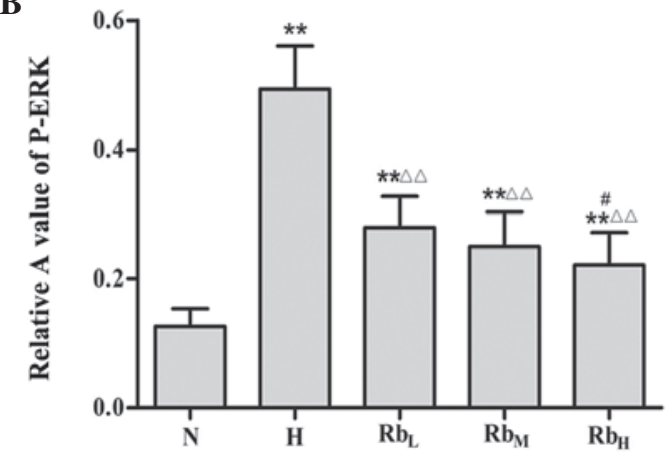

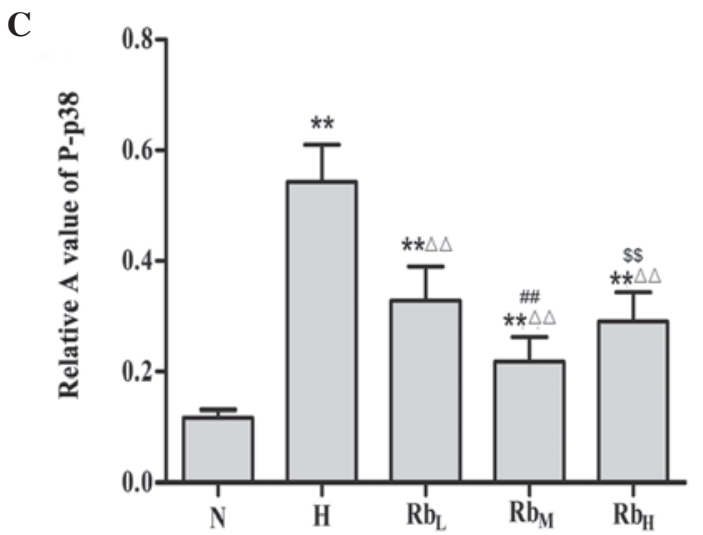

Figure 2. Detection of phosphorylated ERK and p38 protein in the various groups using western blot analysis. (A) Representative immunoblot of P-ERK and P-p38 protein expression; (B) densitometric analysis of relative value of P-ERK protein expression; (C) densitometric analysis of relative value of P-p38 protein expression in different groups. ${ }^{* *} \mathrm{P}<0.01$ vs. $\mathrm{N}$ group; ${ }^{\Delta \Lambda} \mathrm{P}<0.01 \mathrm{vs}$. $\mathrm{H}$ group; ${ }^{\#} \mathrm{P}<0.01$ vs. $\mathrm{Rb}_{\mathrm{L}}$ group; ${ }^{\# \#} \mathrm{P}<0.05 \mathrm{vs}$. $\mathrm{Rb} \mathrm{L}_{\mathrm{L}}$ group; ${ }^{\$ \$} \mathrm{P}<0.01 \mathrm{vs}$. $\mathrm{Rb} \mathrm{M}_{\mathrm{M}}$ group ERK, extracellular signal-regulated kinase; $\mathrm{P}$, phosphorylated; $\mathrm{T}$, total; A, absorbance; $\mathrm{N}$, normal group; $\mathrm{H}$, hypoxia and hypercapnia group; Rb $\mathrm{L}_{\mathrm{L}}$, low dose notoginsenoside $\mathrm{Rb} 1$ (Rb1) group; $\mathrm{Rb}_{\mathrm{M}}$, medium dose $\mathrm{Rb} 1$ group; $\mathrm{Rb} \mathrm{H}_{\mathrm{H}}$, high dose $\mathrm{Rb} 1$ group. Differences between groups were analyzed using one-way analysis of variance.

filaments (SM- $\alpha$-actin) were observed in parallel to the long axis of the cell, with a pale blue oval nucleus located in the center of the cell (Fig. 1C).

Effect of hypoxia/hypercapnia and Rb1 on the protein expression of phosphorylated ERK and p38. P-ERK expression was significantly higher in the $\mathrm{H}$ group compared with the $\mathrm{N}$ group $(\mathrm{P}<0.01)$. Compared with the $\mathrm{H}$ group, the $\mathrm{Rb}_{\mathrm{L}}, \mathrm{Rb}_{\mathrm{M}}$ and $\mathrm{Rb}_{\mathrm{H}}$ groups exhibited decreased expression of P-ERK $(\mathrm{P}<0.01)$. Furthermore, Rb1 suppressed the expression of P-ERK in a dose-dependent manner. The P-ERK expression in the $R b_{H}$ group was significantly lower compared with that in the $\mathrm{Rb}_{\mathrm{L}}$ group $(\mathrm{P}<0.01)$. However, no significant differences were detected between the $R b_{L}$ and $R b_{M}$ groups, nor between the $\mathrm{Rb}_{\mathrm{M}}$ and $\mathrm{Rb}_{\mathrm{H}}$ groups $(\mathrm{P}>0.05$; Fig. $2 \mathrm{~A}$ and $\mathrm{B})$.

Similarly, the H group had elevated P-p38 expression in comparison with the $\mathrm{N}$ group $(\mathrm{P}<0.01)$. $\mathrm{Rb} 1$ treatment led to decreased P-p38 expression in the $\mathrm{Rb}_{\mathrm{L}}, \mathrm{Rb}_{\mathrm{M}}$ and $\mathrm{Rb}_{\mathrm{H}}$ groups compared with the $\mathrm{H}$ group $(\mathrm{P}<0.01)$. Among the three Rb1-treated groups, P-p38 expression was lowest in the $\mathrm{Rb}_{\mathrm{M}}$ group. P-p38 expression was significantly higher in the $\mathrm{Rb}_{\mathrm{L}}$ group compared with the $\mathrm{Rb}_{\mathrm{M}}$ group $(\mathrm{P}<0.01)$. Furthermore, there was no significant difference between the $R b_{L}$ and $\mathrm{Rb}_{\mathrm{H}}$ groups, and between the $\mathrm{Rb}_{\mathrm{M}}$ and $\mathrm{Rb}_{\mathrm{H}}$ groups $(\mathrm{P}>0.05$; Fig. 2A and C).

These results suggest that hypoxia and hypercapnia resulted in the phosphorylation of ERK and p38, which was subsequently inhibited by $\mathrm{Rb} 1$ treatment. The most effective concentrations of $\mathrm{Rb} 1$ for inhibiting the protein expression of P-ERK and P-p38 were 100 and $40 \mathrm{mg} / \mathrm{ml}$, respectively.

Effect of hypoxia and hypercapnia, and Rbl on mRNA expression levels of ERK1, ERK2 and p38. The results of the RT-PCR analysis showed that ERK1 mRNA levels were higher in the $\mathrm{H}$ group compared with the in $\mathrm{N}$ group $(\mathrm{P}<0.01)$. Compared with the $\mathrm{H}$ group, the ERK1 levels were inhibited in the $\mathrm{Rb}_{\mathrm{L}}$, $\mathrm{Rb}_{\mathrm{M}}$ and $\mathrm{Rb}_{\mathrm{H}}$ groups $(\mathrm{P}<0.05)$, but remained higher compared with those in the $\mathrm{N}$ group. Among the three Rb1-treated groups, ERK1 levels were decreased in a dose-dependent manner; however, there were no significant differences among the three groups $(\mathrm{P}>0.05$; Fig. 3A and $\mathrm{B})$.

As with ERK1, the expression of ERK2 was promoted in the $\mathrm{H}$ group compared with the $\mathrm{N}$ group $(\mathrm{P}<0.01)$. This hypoxia and hypercapnia-induced ERK2 promotion was mitigated in the $\mathrm{Rb}_{\mathrm{L}}, \mathrm{Rb}_{\mathrm{M}}$ and $\mathrm{Rb}_{\mathrm{H}}$ groups $(\mathrm{P}<0.05)$. The inhibition of ERK2 by Rb1 exhibited a dose-dependent trend. There were significant differences between the $R b_{L}$ and $\mathrm{Rb}_{\mathrm{M}}$ groups $(\mathrm{P}<0.05)$, and between the $R b_{\mathrm{H}}$ and $\mathrm{Rb}_{\mathrm{L}}$ groups $(\mathrm{P}<0.01)$ (Fig. 3A and $\mathrm{C})$.

Similarly, mRNA levels of p38 were increased in the $\mathrm{H}$ group compared with the $\mathrm{N}$ group $(\mathrm{P}<0.01)$. By contrast, $\mathrm{p} 38$ levels were significantly downregulated in the $\mathrm{Rb}_{\mathrm{L}}, \mathrm{Rb}_{\mathrm{M}}$ and $\mathrm{Rb}_{\mathrm{H}}$ groups in comparison with the $\mathrm{H}$ group $(\mathrm{P}<0.01)$. Among the three groups, $\mathrm{Rb}_{\mathrm{L}}$ had significantly higher p38 levels 
A

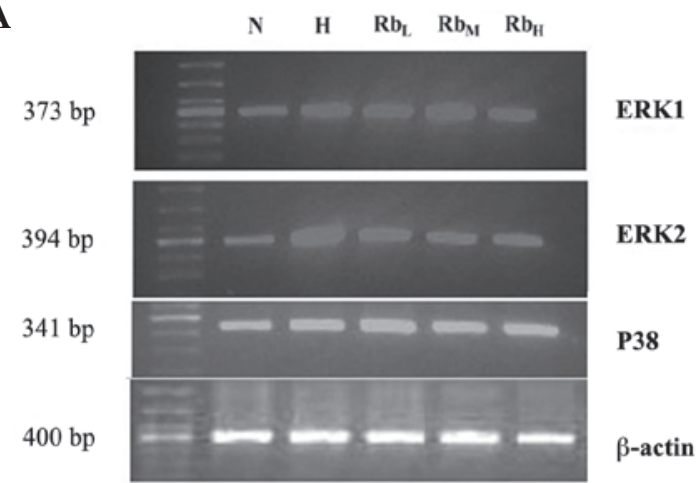

C

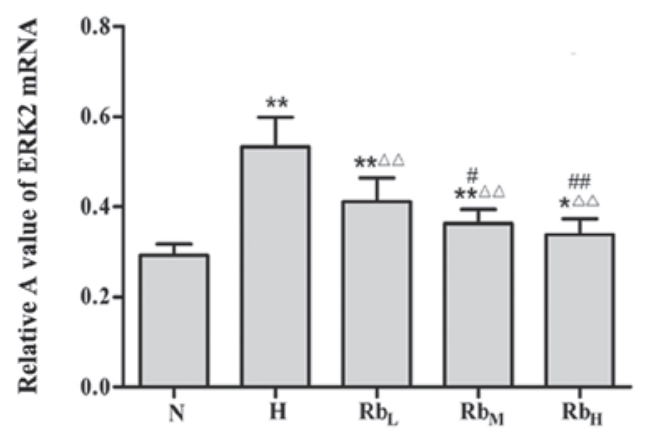

B

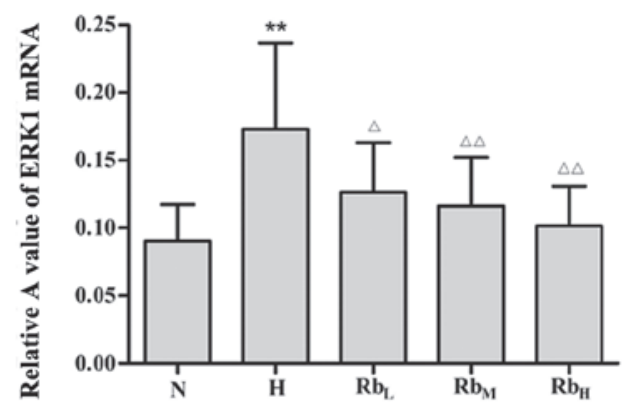

D

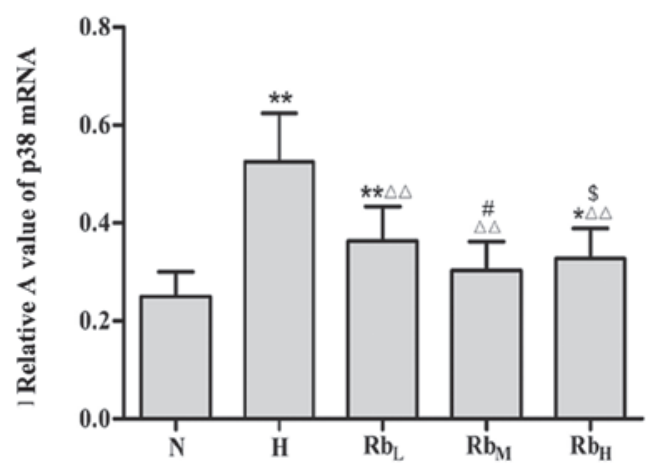

Figure 3. Detection of ERK1, ERK2 and P-38 mRNA in different groups using reverse transcription-polymerase chain reaction. (A) Expression of ERK1, ERK2 and p38 mRNA in different groups; (B) densitometric analysis of relative absorbance (A) value of ERK1 mRNA in different groups; (C) densitometric analysis of relative absorbance (A) value of ERK2 mRNA in the different groups; (D) densitometric analysis of relative A value of p38 mRNA in different groups. ${ }^{*} \mathrm{P}<0.05$ vs. $\mathrm{N}$ group; ${ }^{* *} \mathrm{P}<0.01$ vs. $\mathrm{N}$ group; ${ }^{\Delta} \mathrm{P}<0.05$ vs. $\mathrm{H}$ group; ${ }^{\Delta \Delta} \mathrm{P}<0.01$ vs. H group; ${ }^{\#} \mathrm{P}<0.05$ vs. Rb $b_{\mathrm{L}}$ group; ${ }^{\# \#} \mathrm{P}<0.01$ vs. Rb $\mathrm{L}_{\mathrm{L}}$ group; ${ }^{\$} \mathrm{P}<0.05$ vs. $\mathrm{Rb} \mathrm{b}_{\mathrm{M}}$

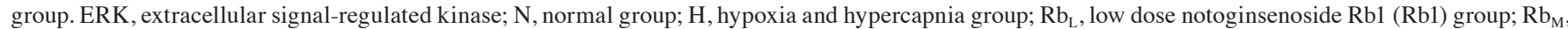
medium dose $\mathrm{Rb} 1$ group; $\mathrm{Rb}_{\mathrm{H}}$, high dose $\mathrm{Rb} 1$ group. Differences between groups were analyzed using one-way analysis of variance.

compared with $\mathrm{Rb}_{\mathrm{H}}$, whereas $\mathrm{Rb}_{\mathrm{H}}$ had significantly higher $\mathrm{p} 38$ levels compared with the $\mathrm{Rb}_{\mathrm{M}}$ group ( $\mathrm{P}<0.05$; Fig. $3 \mathrm{~A}$ and $\left.\mathrm{D}\right)$.

These results indicate that the elevations in ERK1, ERK2 and p38 mRNA levels induced by hypoxia and hypercapnia could be inhibited by Rb1 treatment. The most effective concentration of Rb1 for inhibiting ERK1/2 appeared to be $100 \mathrm{mg} / \mathrm{ml}$, while $40 \mathrm{mg} / \mathrm{ml} \mathrm{Rb1}$ was most effective for the inhibition of $\mathrm{p} 38$.

Analysis of correlation between the expression of P-ERK1/2 protein and ERK1/2 mRNA, and between P-p38 protein and p38 mRNA. As shown in Fig. 4A and B, in the Rb1-treated groups $\mathrm{P}-\mathrm{ERK}$ protein expression was positively correlated with ERK1 mRNA $(r=0.5, \mathrm{P}<0.01)$ and ERK2 $(\mathrm{r}=0.977$, $\mathrm{P}<0.01)$ mRNA expression, respectively. Furthermore, P-p38 protein expression was positively correlated with p38 mRNA ( $\mathrm{r}=0.884, \mathrm{P}<0.01)$ in the Rb1-treated groups (Fig. 4C).

\section{Discussion}

COPD is a present health concern to a substantial number of people, particularly elderly individuals. The increasingly poor air quality appears to promote the incidence of COPD (15). HHPV and PH are common complications of COPD. The results of the present study showed that exposing PASMCs to hypoxia and hypercapnia promoted ERK and p38 phosphorylation at the protein and mRNA level. The promoted ERK and p38 phosphorylation was effectively inhibited by Rb1 treatment.

ERK and p38 pathways serve a variety of functions in a number of biological activities, such as cell proliferation, motility, differentiation and survival (16-18). In vivo and in vitro studies have increasingly indicated that hypoxia could lead to activation of ERK, JNK and p38 pathways, which is involved in pulmonary arteries remodeling $(19,20)$. Furthermore, hypercapnia could result in ERK activation in alveolar epithelial cells in a time-dependent manner (21). In support of these previous studies, the present western blot and RT-PCR results indicated that exposing cells to hypoxia and hypercapnia enhanced the P-ERK protein expression, and ERK1 and ERK2 mRNA expression, respectively. Consistent with ERK, P-p38 protein and p38 mRNA expression were elevated in PASMCs grown under the conditions of hypoxia and hypercapnia.

However, there has been uncertainty regarding the effect of hypercapnia on ERK and p38 expression. For example, it has been observed that ERK and p38 were not involved in the mechanism underlying the attenuation of pulmonary epithelial wound repair by hypercapnic acidosis (22). These contradictory results may be attributed to the varying concentrations of $\mathrm{CO}_{2}$ used in the different experimental models. Another potential explanation is the varied sensitivity of different experimental models to the same concentration of $\mathrm{CO}_{2}$ stimuli. In the present study, the $\mathrm{N}$ group was cultured under 

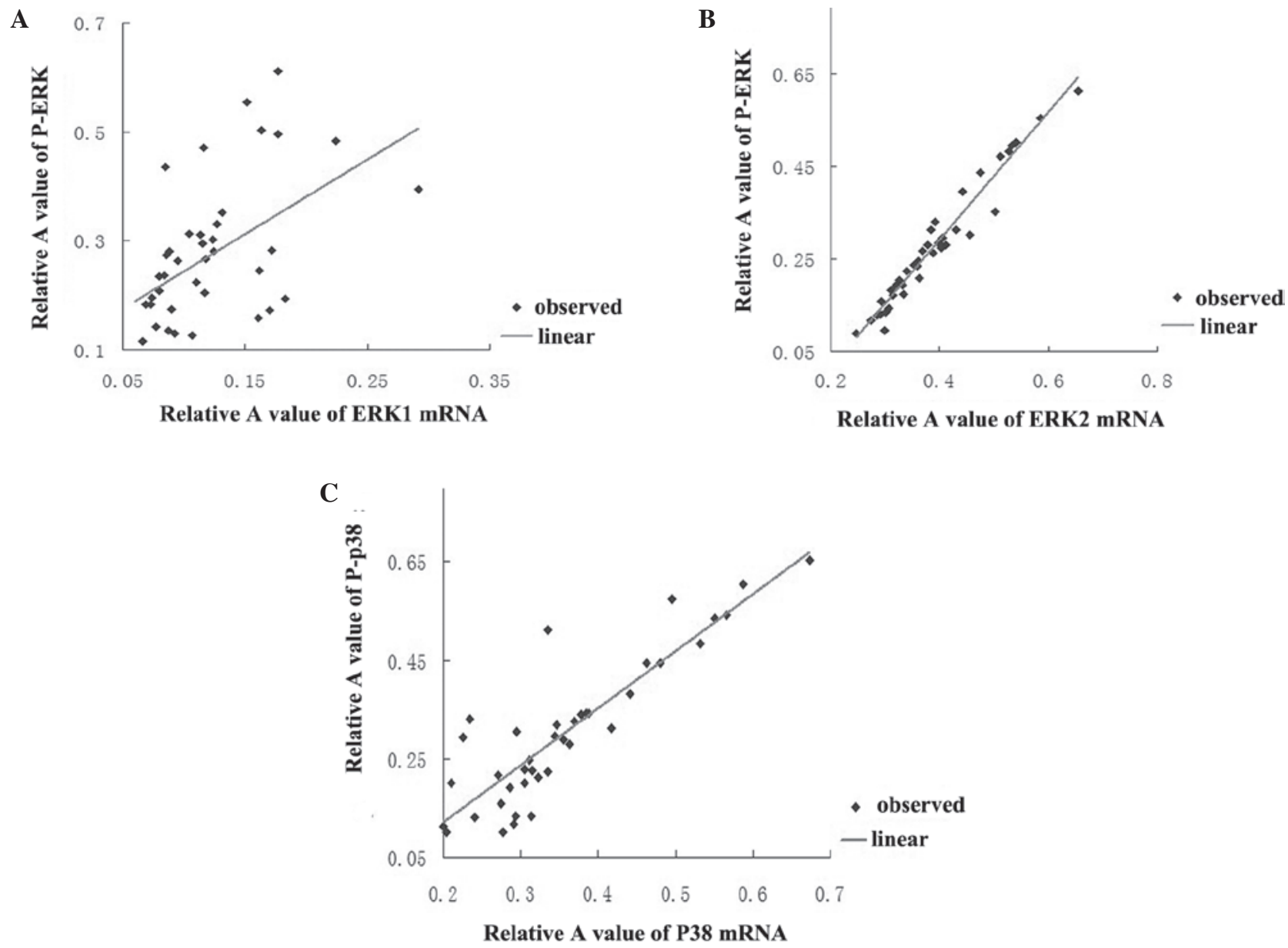

Figure 4. Correlation analysis. (A) Correlation analysis between P-ERK protein and ERK1 mRNA in notoginsenoside Rb1-treated groups ( $\mathrm{r}=0.5$, $\mathrm{P}<0.01$ ); (B) correlation analysis between P-ERK protein and ERK2 mRNA in Rb1-treated groups ( $\mathrm{r}=0.977, \mathrm{P}<0.01)$; (C) correlation analysis between $\mathrm{P}$-p38 protein and $\mathrm{p} 38$ mRNA in Rb1-treated groups $(\mathrm{r}=0.884, \mathrm{P}<0.01)$. The correlation between two variables was evaluated using Pearson's bivariate correlation analysis. ERK, extracellular signal-regulated kinase; P, phosphorylated; A, absorbance.

$5 \% \mathrm{CO}_{2}$ and $21 \% \mathrm{O}_{2}$, while the $\mathrm{H}$ group was grown under $6 \%$ $\mathrm{CO}_{2}$ and $1 \% \mathrm{O}_{2}$. Obviously, hypoxia stimulation produced a stronger impact than hypercapnia on the PASMCs, indicating that the enhanced phosphorylation of ERK and p38 may have predominantly resulted from hypoxia rather than hypercapnia.

It has been established that PNS may function as a free radical-scavenger and suppress ERK, JNK and p38 activation in AS lesion rat models (23). Similarly, Rg1, another active component of PNS, has been reported to protect dopaminergic neurons against 6-hydroxydopamine (6-OHDA) partly by compromising the 6-OHDA-induced ERK phosphorylation (24). Furthermore, it has been observed that ERK activation can be inhibited by R1 (active component of PNS) treatment in human aortic smooth muscle cells (25). In agreement with these studies, Rb1 treatment appeared to suppress the increased P-ERK protein expression, and ERK1/2 mRNA expression induced by hypoxia and hypercapnia. Positive correlations were confirmed between the P-ERK protein and ERK1 mRNA expression, and between the P-ERK protein and ERK2 mRNA expression. Similarly, P-p38 protein and p38 mRNA were significantly reduced in response to $\mathrm{Rb} 1$. $\mathrm{P}-\mathrm{p} 38$ protein levels were positively correlated with $\mathrm{p} 38 \mathrm{mRNA}$ levels. These results indicated that Rb1 may mitigate HHPV via the inhibition of the ERK and p38 pathways. Furthermore, accumulating studies have suggested that hypoxia may promote PASMC proliferation and induce pulmonary vascular remodeling, and subsequently contribute to $\mathrm{PH}$ (26-28). Thus, it is speculated that Rb1 may affect the PASMCs proliferation and pulmonary vascular remodeling via ERK and p38 pathways.

Notably, it was observed that the most effective concentrations of $\mathrm{Rb} 1$ for ERK and $\mathrm{p} 38$ inhibition were 100 and $40 \mathrm{mg} / \mathrm{ml}$, respectively. This indicated a discrepancy of sensitivity to Rb1 treatment between ERK and p38 pathways. The complicated mechanism governing the action of the two pathways has been intensely investigated. Interactions between the two pathways have been demonstrated in regulation of the chondrocyte development (29). The two pathways also function cooperatively in regulating RUNX2 transcription factor phosphorylation and transcriptional activity (30). Furthermore, a variety of signaling pathways such protein kinase A, protein kinase $\mathrm{C}$ and phosphoinositide 3-kinase participate in regulating the downstream ERK and p38 pathways (31-33). Further studies are required to elucidate the relationship between the two pathways in response to $\mathrm{Rb} 1$ treatment.

In conclusion, Rb1 appears to alleviate HHPV by inhibiting the activation of ERK and p38 pathways. The present study indicates the protective activity of $\mathrm{Rb} 1$ in the management of COPD. Future studies are required to evaluate the effect of $\mathrm{Rb} 1$ 
on PASMC proliferation and survival in vivo and in vitro to clarify the underlying mechanism of Rb1 treatment against HHPV.

\section{Acknowledgements}

This study was supported by Zhejiang Province Traditional Chinese Medicine Science and Technology Key Project (grant nos. 2008ZA017 and 2013ZZ011), and Zhejiang Province Traditional Chinese Medicine Key Disciplines Construction Project (grant no. 2012-XK-A28).

\section{References}

1. World Health Organization: The top 10 causes of death, 2000 and 2012. http://www.who.int/mediacentre/factsheets/fs310/en/. Updated May, 2014.

2. Burney $\mathrm{P}$, Jithoo A, Kato B, Janson C, Mannino D, Nizankowska-Mogilnicka E, Studnicka M, Tan W, Bateman E, Kocabas A, et al: Chronic obstructive pulmonary disease mortality and prevalence: The associations with smoking and poverty-a BOLD analysis. Thorax 69: 465-473, 2014.

3. Pauwels RA, Buist AS, Calverley PM, Jenkins CR and Hurd SS; GOLD Scientific Committee: Global strategy for the diagnosis, management and prevention of chronic obstructive pulmonary disease. NHLBI/WHO Global Initiative for Chronic Obstructive Lung Disease (GOLD) Workshop summary. Am J Resp Crit Care 163: 1256-1276, 2001.

4. Kennedy TP, Michael JR, Huang CK, Kallman CH, Zahka K, Schlott W and Summer W: Nifedipine inhibits hypoxic pulmonary vasoconstriction during rest and exercise in patients with chronic obstructive pulmonary disease. A controlled double-blind study. Am Rev Res Dis 129: 544-551, 1984.

5. Seemungal T, Harper-Owen R, Bhowmik A, Moric I, Sanderson G, Message S, Maccallum P, Meade TW, Jeffries DJ, Johnston SL and Wedzicha JA: Respiratory viruses, symptoms and inflammatory markers in acute exacerbations and stable chronic obstructive pulmonary disease. Am J Resp Crit Care Med 164: 1618-1623, 2001.

6. Chaouat A, Naeije R and Weitzenblum E: Pulmonary hypertension in COPD. Eur Respir J 32: 1371-1385, 2008

7. Liu J, Wang Y, Qiu L, Yu Y and Wang C: Saponins of Panax notoginseng: Chemistry, cellular targets and therapeutic opportunities in cardiovascular diseases. Expert Opin Investig Drugs 23: 523-539, 2014.

8. Liu Y, Zhang HG, Jia Y and Li XH: Panax notoginseng saponins attenuate atherogenesis accelerated by zymosan in rabbits. Biol Pharm Bull 33: 1324-1330, 2010.

9. Fan JS, Liu DN, Huang G, Xu ZZ, Jia Y, Zhang HG, Li XH and He FT: Panax notoginseng saponins attenuate atherosclerosis via reciprocal regulation of lipid metabolism and inflammation by inducing liver $\mathrm{X}$ receptor alpha expression. J Ethnopharmacol 142: 732-738, 2012.

10. Wu L, Zhang W, Tang YH, Li H, Chen BY, Zhang GM and Deng CQ Effect of total saponins of 'Panax notoginseng root' on aortic intimal hyperplasia and the expressions of cell cycle protein and extracellular matrix in rats. Phytomedicine 17: 233-240, 2010.

11. Gan J, Li P, Wang Z, Chen J, Liang X, Liu M, Xie W, Yin R and Huang F: Rosuvastatin suppresses platelet-derived growth factor-BB-induced vascular smooth muscle cell proliferation and migration via the MAPK signaling pathway. Exp Ther Med 6 : 899-903, 2013

12. Franceschini A, Szklarczyk D, Frankild S, Kuhn M, Simonovic M, Roth A, Lin J, Minguez P, Bork P, von Mering C and Jensen LJ: STRING v9. 1: Protein-protein interaction networks, with increased coverage and integration. Nucleic Acids Res 41: D808-D815, database issue, 2013.

13. Xu Y,Lin L, Tang L, Zheng M, Ma Y,Huang L, Meng W and Wang W: Notoginsenoside R1 attenuates hypoxia and hypercapnia-induced vasoconstriction in isolated rat pulmonary arterial rings by reducing the expression of ERK. Am J Chinese Med 42: 799-816, 2014.

14. Li X, Lu W, Fu X, Zhang Y, Yang K, Zhong N, Ran P and Wang J: BMP4 increases canonical transient receptor potential protein expression by activating $\mathrm{p} 38 \mathrm{MAPK}$ and ERK1/2 signaling pathways in pulmonary arterial smooth muscle cells. Am J Resp Cell Mol Biol 49: 212-220, 2013
15. Wen FQ and He B. Interpretation of Global Strategy for the Diagnosis, Management and Prevention of Chronic Obstructive Pulmonary Disease (GOLD) (revised 2011). Zhonghua Yi Xue Za Zhi 92: 939-940, 2012 (In Chinese).

16. Roux PP and Blenis J: ERK and p38 MAPK-activated protein kinases: A family of protein kinases with diverse biological functions. Microbiol Mol Biol Rev 68: 320-344, 2004.

17. Kim EK and Choi EJ: Pathological roles of MAPK signaling pathways in human diseases. Biochim Biophys Acta 1802: 396-405, 2010

18. Waseem T, Duxbury M, Ashley SW and Robinson MK: Ghrelin promotes intestinal epithelial cell proliferation through PI3K/Akt pathway and EGFR trans-activation both converging to ERK 1/2 phosphorylation. Peptides 52: 113-121, 2014.

19. Lee SM, Lee CT, Kim YW, Han SK, Shim YS and Yoo CG: Hypoxia confers protection against apoptosis via PI3K/Akt and ERK pathways in lung cancer cells. Cancer Lett 242: 231-238, 2006

20. Jin N, Hatton N, Swartz DR, Xia Xl, Harrington MA, Larsen SH and Rhoades RA: Hypoxia activates jun-N-terminal kinase, extracellular signal-regulated protein kinase and p38 kinase in pulmonary arteries. Am J Respir Cell Mol Biol 23: 593-601, 2000

21. Welch LC, Lecuona E, Briva A, Trejo HE, Dada LA and Sznajder JI: Extracellular signal-regulated kinase (ERK) participates in the hypercapnia-induced $\mathrm{Na}, \mathrm{K}-\mathrm{ATPase}$ downregulation. FEBS Lett 584: 3985-3989, 2010.

22. O'Toole D, Hassett P, Contreras M, Higgins BD, McKeown ST, McAuley DF, O'Brien T and Laffey JG: Hypercapnic acidosis attenuates pulmonary epithelial wound repair by an NF-kappaB dependent mechanism. Thorax 64: 976-982, 2009.

23. Dou L, Lu Y, Shen T, Huang X, Man Y, Wang $S$ and Li $\mathrm{J}$ : Panax notogingseng saponins suppress RAGE/MAPK signaling and NF-kappaB activation in apolipoprotein-E-deficient atherosclerosis-prone mice. Cell Physiol Biochem 29: 875-882, 2012.

24. Ge KL, Chen WF, Xie JX and Wong MS: Ginsenoside Rg protects against 6-OHDA-induced toxicity in MES23. 5 cells via Akt and ERK signaling pathways. J Ethnopharmacol 127: $118-123,2010$.

25. Zhang HS and Wang SQ: Notoginsenoside R1 inhibits TNF-alpha-induced fibronectin production in smooth muscle cells via the ROS/ERK pathway. Free Radical Bio Med 40: 1664-1674, 2006

26. Penumatsa KC, Toksoz D, Warburton RR, Hilmer AJ, Liu T, Khosla C, Comhair SA and Fanburg BL: Role of hypoxia-induced transglutaminase 2 in pulmonary artery smooth muscle cell proliferation. Am J Physiol Lung Cell Mol Physiol 307: L576-L585, 2014.

27. ShanR,ChenL,LiX,WuH,LiangQ and TangX:Hypoxia promotes rabbit pulmonary artery smooth muscle cells proliferation through a 15-LOX-2 product 15(S)-hydroxyeicosatetraenoic acid. Prostaglandins Leukot Essent Fatty Acids 86: 85-90, 2012.

28. Wei L, Yu X, Shi H, Zhang B, Lian M, Li J, Shen T, Xing Y and Zhu D: 15-PGDH/15-KETE plays a role in hypoxia-induced pulmonary vascular remodeling through ERK1/2-dependent PAR-2 pathway. Cell Signal 26: 1476-1488, 2014.

29. Hutchison MR: BDNF alters ERK/p38 MAPK activity ratios to promote differentiation in growth plate chondrocytes. Mol Endocrinol 26: 1406-1416, 2012.

30. Ge C, Yang Q, Zhao G, Yu H, Kirkwood KL and Franceschi RT: Interactions between extracellular signal-regulated kinase 1/2 and P38 Map kinase pathways in the control of RUNX2 phosphorylation and transcriptional activity. J Bone Miner Res 27: 538-551, 2012.

31. de Araújo Herculano B, Vandresen-Filho S, Martins WC, Boeck CR and Tasca CI: NMDA preconditioning protects against quinolinic acid-induced seizures via PKA, PI3K and MAPK/ERK signaling pathways. Behav Brain Res 219: 92-97, 2011.

32. Hirota Y, Tsukazaki T, Yonekura A, Miyazaki Y, Osaki M, Shindo $\mathrm{H}$ and Yamashita S: Activation of specific MEK-ERK cascade is necessary for TGF $\beta$ signaling and crosstalk with PKA and PKC pathways in cultured rat articular chondrocytes. Osteoarthr Cartilage 8: 241-247, 2000

33. Zhou D, Liu Y, Zhang X, Gu X, Wang H, Luo X, Zhang J, Zou H and Guan M: Functional polymorphisms of the ABCG2 gene are associated with gout disease in the Chinese Han male population. Int J Mol Sci 15: 9149-9159, 2014. 